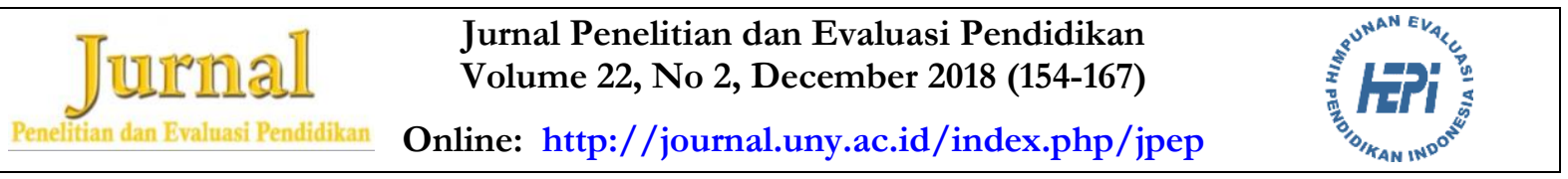

\title{
EVALUASI PROGRAM MAHASISWA WIRAUSAHA DENGAN MODEL CIPO DI UNIVERSITAS BRAWIJAYA DAN UNIVERSITAS NEGERI MALANG
}

\author{
Ahmad \\ Universitas Gajayana Malang \\ Jl. Mertojoyo Blok L, Merjosari Malang, Jawa Timur, 65144 Indonesia \\ Email: ahmad_t@unigamalang.ac.id
}

\begin{abstract}
Abstrak
Penelitian ini bertujuan untuk mengevaluasi implementasi kebijakan Program Mahasiswa Wirausaha pada Universitas Brawijaya dan Universitas Negeri Malang di Jawa Timur. Penelitian ini menggunakan pendekatan evaluatif yang berbasis kasus pada kedua universitas pelaksana PMW dengan metode evaluasi program dengan model CIPO. Hasil penelitian menunjukkan: (1) Konteks evaluasi, suatu perencanaan PMW merujuk pada latar belakang, landasan formal dan operasional pelaksanaan, tujuan, dan manfaat bagi pemangku kepentingan dengan capaian evaluasinya tinggi; (2) Input evaluasi, adanya perbedaan mekanisme pengalokasian dana bantuan antara PMW-UB dan PMW-UM yang menyebabkan capaian evaluasinya moderat, sedangkan pada indikator lain capaian evaluasinya tinggi; (3) Proses evaluasi, terdapat enam belas kriteria evaluasi yang berkategori tinggi, enam kriteria evaluasi yang berkategori moderat dan dua kriteria evaluasi yang berkategori rendah; sedangkan (4) Output evaluasi, indikator mahasiswa yang berwirausaha dan unit usaha yang dikembangkan mahasiswa dengan evaluasi capaiannya rendah.

Kata kunci: program mahasiswa wirausaba, model evaluasi CIPO

\section{EVALUATION OF STUDENT ENTREPRENEUR PROGRAM WITH CIPO MODEL IN BRAWIJAYA UNIVERSITY AND THE STATE UNIVERSITY OF MALANG}

\begin{abstract}
This research is aimed at evaluating the implementation of the Student Entrepreneurial Program policies at Brawijaya University and the State University of Malang in East Java. This study uses a case-based evaluative approach at both University, Brawijaya University and the State University of Malang with program evaluation methods. The model used in this research was CIPO model. The results showed: Context evaluation, a PMW planning refers to background, formal foundation and operational implementation, purpose, and benefits for the stakeholders to the achievement of a high evaluation; Input evaluation, the difference in the mechanism of allocating funds between PMW-UB and PMW-UM is causing moderate evaluation outcomes, whereas the other indicators of high achievement evaluation; Process evaluation, there are sixteen high-category evaluation criteria, six criteria of moderate categorization and two low evaluation criteria; and outputs evaluation, indicators student entrepreneurship and business unit developed a student with low achievements evaluation.
\end{abstract}

Keywords: student entrepreneurship program, CIPO evaluation model

Permalink/DOI: http://dx.doi.org/10.21831/pep.v22i2.16577

Jurnal Penelitian dan Evaluasi Pendidikan

ISSN 2338-6061 (online) 


\section{Pendahuluan}

Jawa Timur yang dinobatkan sebagai provinsi terpadat kedua di Indonesia memiliki populasi penduduk 38.106.600 jiwa dari 245.425.200 jiwa masyarakat Indonesia $(\mathrm{Pu}-$ sat Data Statistik Pendidikan, 2014, p. 13), yang terbagi dalam tiga suku daerah yakni Madura, Using, dan Tengger (MUT) yang memiliki karakter dan budaya yang berbedabeda. Selain itu tingkat kepadatan penduduk mencapai 15,53\% menjadikan Jawa Timur memiliki pengaruh yang besar terhadap perkembangan ekonomi Nasional.

Diasumsikan dengan semakin meningkatnya populasi penduduk suatu daerah akan sebanding dengan peningkatan kesejahteraan rakyatnya (Soenarto, Amin, \& Kumaidi, 2017, p. 216). Akan tetapi kondisi terkini di Jawa Timur berbanding terbalik dengan asumsi yang ada, dengan tingkat pengangguran terbuka (TPT) pada Agustus 2014 mencapai 4,19\% mendekati TPT rata-rata nasional 6,25\% dari 245,425 juta jiwa penduduk Indonesia, (Badan Pusat Statistik Provinsi Jawa Timur, 2014). Angkatan kerja di Jawa Timur usia 15 tahun ke atas per Agustus 2014 berjumlah 20.149.990 jiwa, diantaranya 19.306.510 jiwa bekerja dan 843.490 jiwa masih menganggur. Penduduk yang bekerja tersebut berkurang sebanyak 247 ribu orang dibanding keadaan Agustus 2013 yang jumlahnya sebanyak 19,55 juta orang (Badan Pusat Statistik Provinsi Jawa Timur, 2014, p. 4).

Idealnya bonus demograsi tersebut menjadi peluang tersendiri bagi provinsi Jawa Timur menjadi sentral ekonomi nasional yang memiliki sumber daya manusia yang berkualitas, dengan sumber daya manusia yang berkualitas dapat mengelola sumber daya manusia secara optimal (Sutopo, 2012, p. 421). Akan tetapi momok yang bernama pengangguran masih menghantui setiap lini kehidupan. Karena pengangguran merupakan dilema klasik yang terus berevolusi disetiap dinding kehidupan manusia berbangsa dan bernegara. Kondisi demikian terjadi karena tingginya suplai tidak sebanding dengan jumlah permintaan yang tersedia. Pengangguran juga terjadi karena keterbatasan sumber daya ma- nusia yang potensial, kompetitif, inovatif, kreatif dan mandiri, Suyanto \& Ariadi (2015, p. 116). Untuk menggerakkan laju perekonomian nasional, pemerintah mencanangkan gerakan kewirausahaan nasional. Gerakan tersebut dapat berjalan efektif apabila elemen akademisi, bisnis, dan pemerintah berjalan bersama dalam pembangunan (Siradjuddin, 2009, p. 291).

Namun keterpaduan elemen tersebut belum berjalan seperti yang diharapkan, hal ini ditandai dengan masih tingginya angka pengangguran terdidik berpendidikan tinggi di Indonesia mencapai angka 5,96 juta jiwa (Badan Pusat Statistik, 2013), bahkan diproyeksikan akan terus meningkat pada tahuntahun berikutnya karena masih terdapat $36,81 \%$ penduduk usia $20-30$ tahun yang bekerja paruh waktu. Kondisi demikian menjadi perhatian Subianto (2013, p. 68) yang menyatakan bahwa jumlah pengangguran dengan tingkat pendidikan sarjana relatif meningkat dari tahun ke tahun, sementara dunia usaha dan dunia kerja setiap tahun juga mengalami kesulitan untuk mendapatkan tenaga kerja baru yang memiliki kualifikasi pendidikan serta keterampilan yang sesuai.

Penyebab utamanya karena pola pikir masyarakat Indonesia masih menganut pola pikir mencari pekerjaan (job seeker), minat dan aktivitas kewirausahaan (entrepreneurial activity) tenaga berpendidikan tinggi relatif rendah untuk mampu berwirausaha dan bekerja secara mandiri (Suyanto \& Ariadi, 2015). Faktor tingkat pendidikan yang tidak relevan dengan kebutuhan lapangan kerja juga menyumbang lahirnya penganggur terdidik di Indonesia. Menurut Tilaar \& Nugroho (2012, p. 13) sedikitnya ada tiga hal yang menjadi alasan utama kenapa alumni perguruan tinggi banyak yang tidak bekerja, yaitu hambatan kultural, mutu dan relevansi kurikulum pendidikan, dan pasar kerja.

Menurut McClelland (Ciputra, 2008), suatu negara menjadi makmur apabila didukung oleh minimum jumlah wirausahawannya $2 \%$ dari populasi penduduk suatu negara. Namun realitas menunjukkan bahwa jumlah wirausaha di Indonesia baru berada pada angka 1,65\%, atau sebanyak 4,20 juta dari 
118,17 juta orang penduduk Indonesia yang bekerja, sedangkan Amerika Serikat di tahun 2013 jumlah wirausahanya $11,5 \%$, China $10 \%$, Jepang dengan jumlah wirausaha $10 \%$, Singapura 7,2\% dan Malaysia 5\% (Ariyanti, 2013).

Istilah wirausaha pertama kali diperkenalkan di dunia pada tahun 1725 oleh ahli ekonomi berkebangsaan Perancis yang bernama (Cantillon, 2010, p. 75), berwirausaha merupakan sebuah upaya untuk bekerja sendiri, membeli dengan harga yang telah ditentukan, kemudian menjualnya di pasar dengan harga yang telah ditentukan. Kemudian tahun 1776 Adam Smith dalam kritikannya yang berjudul Discussed entrepreneur but associated activities with the capitalist, pada generasi JeanBaptiste Say tahun 1803 dalam tulisannya Defined entrepreneur as improving the state of resources used in production yang makin mengantarkan konsep kewirausahaan makin mendunia, sehingga di tahun 1871 John Stuart Mill Associated capitalist and entrepreneur together through risk dan sampai tahun 1934 Joseph A. Schumpeter melalui tulisannya berjudul Defined entrepreneurs as sociologically distinct individuals; separated entrepreneurship from the role of the capitalist.

Dengan demikian, menurut Joseph Schumpeter (Bygrave, 2010, p. 2), wirausaha adalah orang yang mendobrak sistem ekonomi yang ada dengan memperkenalkan barang dan jasa yang baru, dengan menciptakan bentuk organisasi baru atau mengolah bahan baku baru. Orang tersebut melakukan kegiatannya melalui organisasi bisnis yang baru ataupun bisa pula dilakukan dalam organisasi bisnis yang sudah ada.

Menurut Akbar (2007, p. 37) wirausaha dipergunakan untuk menggambarkan aktivitas manusia yang memaksimalkan sumber daya yang ada untuk menghasilkan produktivitas yang tinggi. Pandangan terhadap wirausaha dapat diartikan sebagai profesi pada dunia usaha di bidang bisnis dan dipandang sebagai sikap mental, ciri pribadi, atau nilai-nilai yang dapat dimiliki oleh siapapun.

Dengan demikian wirausaha adalah manusia yang memiliki kepribadian unggul, berani mengambil resiko, kebulatan tekad secara mandiri, dan tangguh untuk menciptakan suatu organisasi baru atau memanfaatkan organisasi yang sudah ada dan menggunakan modal sebagai alat bantu dalam proses penciptaan kreativitas dan inovatif guna mencapai tingkat produktivitas yang tinggi sebagai hasil dari aktivitas wirausaha. Aktivitas dari wirausaha disebut kewirausahaan.

Terminologi kewirausahaan adalah semangat, sikap dan perilaku atau kemampuan seseorang dalam menangani usaha dan atau kegiatan yang mengarah pada upaya mencari, menciptakan, menerapkan cara kerja, teknologi, dan produk baru dengan meningkatkan efisiensi dalam rangka memberikan pelayanan yang lebih baik dan atau memperoleh keuntungan yang lebih besar.

Sebagaimana definisi dari Hisrich, Peters, \& Shepherd (2008, p. 10) kewirausahaan adalah proses penciptaan sesuatu yang baru pada nilai menggunakan waktu dan upaya yang diperlukan, menanggung resiko keuangan, fisik, serta resiko sosial yang mengiringi, menerima imbalan moneter yang dihasilkan serta kepuasan dan kebebasan pribadi. Schumpeter sebagaimana dikutip Alma (2011, p. 24), mendefinisikan kewirausahaan adalah jiwa seseorang yang mendobrak sistem ekonomi yang ada dengan memperkenalkan barang dan jasa yang baru, dengan menciptakan bentuk organisasi baru. Karena dalam kewirausahaan membutuhkan suatu proses kreasi, dan inovatif, serta beresiko tinggi dalam menghasilkan nilai tambah bagi produk yang bermanfaat bagi masyarakat dan mendatangkan kemakmuran bagi wirausahawan.

Kewirausahaan itu dapat dipelajari walaupun ada juga orang-orang tertentu yang mempunyai bakat dalam hal berwirausaha. Oleh karena itu, untuk menekan angka pengangguran terdidik di Indonesia, Direktorat Jenderal Pendidikan Tinggi mengeluarkan kebijakan meningkatkan kewirausahaan mahasiswa (Direktorat Jenderal Pendidikan Tinggi Kementerian Pendidikan dan Kebudayaan, 2009, p. 3) supaya lulusan perguruan tinggi mampu menggerakkan perekonomian serta meningkatkan kesejahteraan masyarakat. 
Hal ini sebagaimana pernyataan Ciputra (Siradjuddin, 2009, p. 107), pendidikan kewirausahaan adalah senjata penghancur massal mengatasi pengangguran dan kemiskinan sekaligus tangga menuju impian setiap warga negara untuk mandiri secara finansial dan mampu membangun kemakmuran untuk bersama-sama membangun kesejahteraan bangsa.

Kebijakan dan program penguatan kelembagaan perguruan tinggipun dikembangkan melalui Program Mahasiswa Wirausaha (Student Entrepreneur Program) disingkat PMW yang dirintis sejak tahun anggaran 2009. PMW bertujuan untuk membekali mahasiswa dengan pengetahuan, keterampilan dan jiwa wirausaha berbasis ilmu pengetahuan, teknologi dan sains kepada para mahasiswa agar menjadi calon pengusaha yang tangguh dan sukses menghadapi persaingan global. Sasaran lainnya adalah untuk meningkatkan aktivitas kewirausahaan bagi para mahasiswa sebelum lulus agar mampu menjadi wirausaha yang tangguh dimasa yang akan datang.

Untuk menciptakan wirausaha berpendidikan tinggi, sejak tahun 2009-2013 Universitas Brawijaya (UB), dan Universitas Negeri Malang (UM) sebagai representasi dari Dirjen Dikti telah menyelenggarakan PMW secara berkelanjutan dimulai dari proses sosialisasi, rekruitmen, pelatihan, magang, bantuan permodalan, pelaksanaan usaha, mentoring, dan pameran produk PMW. Oleh karena itu, pelaksanaan PMW pada kedua universitas diharapkan dapat menumbuhkembangkan jiwa kewirausahaan dan meningkatkan aktivitas kewirausahaan agar para lulusan perguruan tinggi lebih menjadi pencipta lapangan kerja dari pada pencari kerja.

PMW merupakan kelanjutan dari program-program sebelumnya (PKM, Co-op, $\mathrm{KKU}$, dll) untuk menjembatani para mahasiswa memasuki dunia bisnis riil melalui fasilitas star-up bussines. Disamping itu juga, pelaksanaan PMW pada kedua universitas terfokus dalam mengimplementasikan visi UB menuju Entrepreneurial University, dan UM dengan pijakan menuju the learning university yang berdasarkan pola pengembangan kemahasiswaan yang bertumpu pada pilar percepatan adaptasi, perolehan prestasi, dan pendekatan dunia kerja.

Pelaksanaan PMW secara nasional sejak tahun 2009-2014 belum dilakukan evaluasi, karena demikian maka sangat penting dilakukan evaluasi terhadap pelaksanaan program tersebut dengan tujuan untuk mengetahui tingkat keberhasilan program. Dewasa ini banyak model evaluasi program yang dihasilkan, namun menimbulkan permasalahan sendiri bagi para praktisi dan pengguna model evaluasi program tentang model terbaik sesuai dengan tujuan. Setiap model evaluasi dikembangkan berdasarkan asumsi tentang model evaluasi yang seperti apa dan menggunakan pendekatan yang bagaimana untuk mengevaluasi suatu program.

Beragam model evaluasi program tersebut, akan disesuaikan dengan karakteristik program yang akan dievaluasi. Indikator lainnya adalah berangkat dari kerangka teori yang dibangun untuk menunjang komponen program yang akan dievaluasi, walaupun dalam penelitian ini dibatasi pada empat komponen utama yakni komponen konteks, input, proses, dan output. Sebagaimana pendapat Scheerens, Glas, \& Thomas (2003) sebagai pakar evaluasi context, input, prosses, dan output (CIPO) memaklumi bahwa suatu model evaluasi program yang dikembangkan tidak semestinya dapat memenuhi semua kebutuhan komponen program, akan tetapi dengan model evaluasi program yang ada disesuaikan dengan komponen apa yang dievaluasi.

Berdasarkan pendapat Scheerens tersebut, dan memperhatikan karakteristik dari kebijakan PMW yang akan di evaluasi, maka dalam penelitian ini dibatasi menggunakan evaluasi model CIPO yang fokus mengkaji komponen konteks, input, proses, dan output yang dikembangkan oleh Scheerens yang diadopsi dari sekolah model.

Penggunaan model evaluasi CIPO merupakan kritikan dari keterbatasan model evaluasi CIPP akan pentingnya komponen output pada setiap tingkatan evaluasi. Karena keterbatasan tersebut, sebagai ciri dari ilmu pengetahuan yang selalu mengalami perkembangan maka dengan sendirinya model evaluasi program yang dapat mengevaluasi 
output bermunculan. Oleh sebab itu, untuk mengetahui efektivitas pelaksanaan PMW maka sangat penting untuk dilakukan penelitian dengan judul "Evaluasi Program Mahasiswa Wirausaha Dengan Model CIPO Di Universitas Brawijaya dan Universitas Negeri Malang. Diharapkan dengan penelitian ini dapat memberikan kontribusi nyata dalam perbaikan mutu pembangunan manusia, pendidikan, dan kesejahteraan nasional.

\section{Metode Penelitian}

Penelitian telah dilaksanakan di UB dan UM di Jawa Timur. Pemilihan kedua universitas tersebut karena secara bersamasama telah melaksanakan PMW secara berkelanjutan sejak tahun 2009 sampai tahun 2014 yang dibuktikan dengan laporan pertanggungjawaban program setiap tahun dan kedua universitas tersebut juga samasama mendapat predikat 40 besar perguruan tinggi terbaik, dan 25 besar perguruan tinggi negeri terbaik di Indonesia tahun 2014. Subjek dalam penelitian ini berjumlah 39 orang yang berasal dari mahasiswa peserta PMW, perwakilan dari Dikti, perwakilan dari UB, dan perwakilan dari UM. Subjek dalam penelitian ini yakni terdiri dari 15 mahasiswa UB dan 15 mahasiswa UM, perwakilan Dikti diwakili oleh 3 subjek kunci, pelaksana PMW yang terdiri dari 3 subjek kunci dari UB dan 3 subjek kunci dari UM.

Adapun informasi yang dikaji terpetakan berdasarkan komponen evaluasi yakni: (1) komponen konteks menggali informasi tentang latar belakang PMW, dasar penyusunan PMW, tujuan penyusunan PMW, dan manfaat PMW, (2) komponen input, untuk mengkaji bentuk pedoman pelaksanaan PMW, struktur organisasi pelaksana PMW, mekanisme pembiayaan/pendanaan, kualitas kurikulum, dan sarana dan prasarana penunjang PMW, (3) komponen proses melalui penelusuran dokumen tentang mekanisme sosialisasi program, sistem seleksi peserta PMW, mekanisme pelatihan dan pembekalan, magang dan pendampingan usaha, mekanisme pencairan modal usaha awal, monitoring dan evaluasi usaha PMW, (4) komponen output untuk mengevaluasi tren perkembangan jumlah mahasiswa wirausaha, dan jumlah unit bisnis yang berhasil dikembangkan dalam PMW. Informasi tersebut diperoleh melalui penyebaran kuesioner dan wawancara. Kuesioner terbagi dalam dua paket yakni kuesioner untuk pengelola PMW dan kuesioner untuk mahasiswa peserta PMW. Kedua paket kuesioner tersebut di validasi oleh 20 orang panelis terdiri dari unsur akademisi, praktisi pendidikan, dan pelaksana PMW di universitas. Hasil validasi panelis terhadap 46 butir kuesioner untuk pengelola PMW, terdapat 42 butir yang valid, sedangkan 4 butir lainnya tidak valid yakni butir nomor 1 , 19, 21, dan 25. Walaupun hasil analisis menunjukkan 42 butir sudah valid, namun peneliti tetap melakukan revisi kuesioner dari segi konstruksi dan bahasa, sedangkan butir yang tidak valid peneliti langsung membuangnya setelah memastikan tidak mempengaruhi aspek, dan indikator evaluasi.

Hasil penguiian validasi butir diperoleh $\mathrm{CVR}_{\text {total }}=0,83$ sedangkan kriteria untuk menentukan valid tidaknya isi butir instrumen dengan jumlah panelis 20 orang yakni dengan syarat $\mathrm{CVR}_{\text {hitung }} \geq \mathrm{CVR}_{\text {tabel }} 0,42$ (Lawshe, 1975, p. 568). Oleh karena CVR total melebihi kriteria kritis CVR maka butir soal dinyatakan baik untuk digunakan.

Kemudian, hasil validasi panelis terhadap 30 butir kuesioner untuk mahasiswa peserta PMW, diperoleh 27 butir yang valid dan 3 butir tidak valid yakni butir nomor 6 , 17, dan 28. Walaupun hasil analisis menunjukkan 27 butir sudah valid, namun peneliti tetap melakukan revisi terhadap kuesioner dari segi konstruksi dan bahasa.

Hasil pengujian validasi butir diperoleh $\mathrm{CVR}_{\text {total }}=0,84$ sedangkan kriteria untuk menentukan valid tidaknya isi butir kuesioner dengan jumlah panelis 20 orang yakni dengan syarat $\mathrm{CVR}_{\text {hitung }} \geq \mathrm{CVR}_{\text {tabel }} 0,42$. Oleh karena $\mathrm{CVR}_{\text {total }}$ melebihi kriteria kritis CVR maka butir soal dinyatakan baik untuk digunakan.

Kriteria keberhasilan PMW dibuat dalam bentuk kategori yakni dengan kategori evaluasi tinggi, moderat, dan rendah terhadap pelaksanaan kebijakan PMW pada kedua universitas. 
Tabel 1. Kriteria Evaluasi

\begin{tabular}{ll}
\hline Kriteria & \multicolumn{1}{c}{ Deskripsi } \\
\hline Rendah & $\begin{array}{l}\text { Kriteria evaluasi tidak terpenuhi } \\
\text { semuanya atau terpenuhi } \\
\text { sebagian di bawah } 50 \% \text { dari } \\
\text { kriteria yang ditetapkan }\end{array}$ \\
\hline Moderat & $\begin{array}{l}\text { Kriteria evaluasi terpenuhi } \\
\text { sebagian, 50\% atau lebih dari } \\
\text { kriteria yang ditetapkan }\end{array}$ \\
\hline Tinggi & $\begin{array}{l}\text { Kriteria evaluasi terpenuhi } \\
\text { semua }\end{array}$ \\
\hline
\end{tabular}

Penelitian ini menggunakan pendekatan evaluatif yang berbasis kasus pada kedua Universitas pelaksana PMW, dengan metode penelitian evaluasi program.

\section{Hasil Penelitian dan Pembahasan}

Berdasarkan hasil penelitian terhadap pelaksanaan kebijakan PMW pada kedua universitas yang menjadi target tempat penelitian, maka hasil penelitian secara umum dapat didistribusikan seperti pada tabel dua berikut.

Tabel 2. Hasil Evaluasi Program Mahasiswa Wirausaha

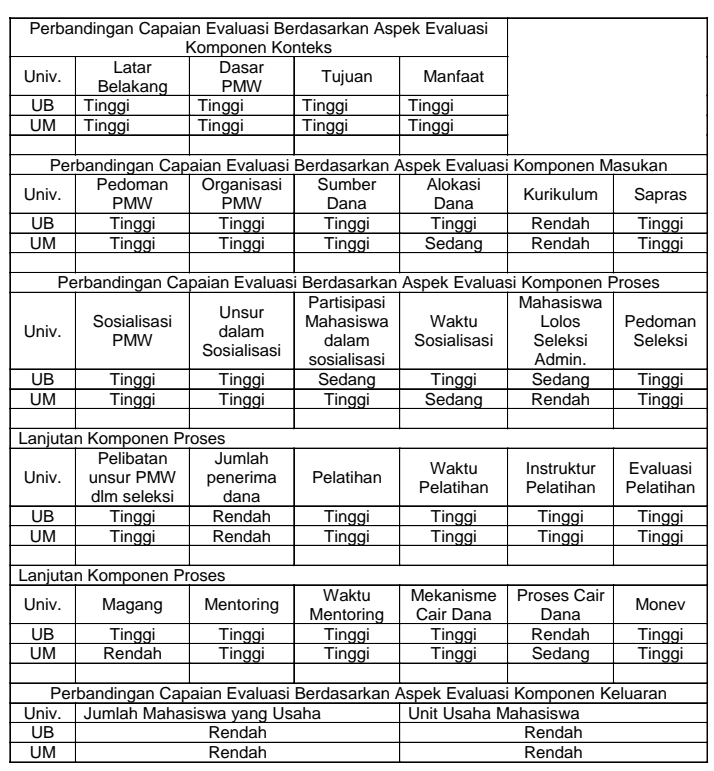

Berdasarkan hasil penelitian sebagaimana pada Tabel 2, pada komponen evaluasi konteks, secara umum pelaksanaan PMW pada kedua universitas tersebut tergolong tinggi. Hasil komponen evaluasi masukan menunjukkan pelaksanaan PMW pada kedua universitas tersebut tergolong tinggi, akan tetapi masih terdapat indikator evaluasi yang berstatus moderat dan indikator berstatus rendah. Komponen evaluasi proses menunjukkan bahwa terdapat dua belas indikator berkategori tinggi, lima indikator berkategori moderat, dan satu indikator berkategori rendah. Untuk komponen evaluasi output semua indikator berkategori rendah. Hasil penelitian ini lebih lanjut dapat dijelaskan pada pokok pembahasan berikut.

\section{Pembahasan}

Berdasarkan deskripsi temuan penelitian, maka perlu dilakukan pembahasan pada setiap komponen hasil penelitian. Adapun pembahasan temuan penelitian dapat diuraikan sebagai berikut.

\section{Komponen Konteks (Context)}

\section{Latar Belakang Pelaksanaan}

Hasil penelitian menunjukkan aspek evaluasi tentang latar belakang program dengan capaian kategori tinggi. Hal ini sesuai dengan arah pengembangan PMW pada kedua universitas sesuai dengan karakteristik universitas yang terintegrasi dengan visi, misi, arah pengembangan dan tujuan pada kedua universitas. Semangat Worldclass Entrepreneur University dan The Learning University pada kedua universitas tersebut berkontribusi perkembangan pendidikan nasional, karena pendidikan dewasa ini bukan saja berorientasi pendidikan untuk pendidikan, namun pendidikan yang memuat/implikasi pengetahuan, skill, dan mental.

Khususnya pendidikan di universitas bukan saja thingking the job namun creating the job, karena output dari pendidikan seharusnya mengembangkan ilmu dan teknologi melalui usaha-usaha bisnis salah satunya sebagaimana dalam penerapan PMW dengan tujuan untuk membentuk mahasiswa yang memiliki pola pikir creating the job. Untuk menumbuhkembangkan jiwa kewirausahaan dan meningkatkan aktivitas kewirausahaan mahasiswa maka terbentuk program pengembangan budaya kewirausahaan seperti 
Program Kreativitas Mahasiswa (PKM), Cooperative Education (Co-op), Kuliah Kewirausahaan (KWU), Magang Kewirausahaan $(\mathrm{MKU})$, Kuliah Kerja Usaha (KKU), dan Karya Alternatif Mahasiswa (KAM).

\section{Landasan Penyusunan}

Hasil penelitian pada aspek landasan penyusunan PMW kedua universitas berkategori tinggi. Hasil ini ditunjang baik secara formal dan operasional, landasan pelaksanaan PMW mengacu pada undang-undang, peraturan pemerintah, peraturan menteri, keputusan Direktur Jenderal, regulasi anggaran dan Surat Keputusan Rektor setiap universitas sebagai bentuk komitmen universitas pada setiap kegiatan PMW. Sejumlah regulasi tersebut dapat terbagi dalam dua kelompok utama yakni regulasi formal umum dan regulasi formal operasional. Regulasi formal umum yang terdiri dari undang-undang, peraturan pemerintah, peraturan menteri, keputusan menteri yang bersifat umum sebagai landasan penyelenggaraan program, sedangkan regulasi formal operasional yang merupakan landasan gerak yang mengikat secara langsung terhadap pelaksanaan program di lapangan seperti surat keputusan rektor pada setiap universitas.

\section{Tujuan}

Hasil penelitian pada aspek tujuan PMW kedua universitas tersebut berkategori tinggi. Hasil ini ditandai dengan adanya tujuan PMW yang ditetapkan oleh Dikti sebagai tujuan umum, namun kedua universitas diberikan ruang untuk mengembangkan tujuan khusus sesuai dengan kebutuhan setiap universitas. Berangkat dari tujuan itu pula universitas merancang dan menyusun program, perangkat organisasi pelaksana sehingga sasaran program untuk menciptakan wirausaha yang berpendidikan tinggi, terbentuknya model pembelajaran dan unit kewirausahaan di universitas tercapai. Untuk mencapai target tersebut di atas maka ditetapkan strategi pengembangan kewirausahaan mahasiswa meliputi: (1) pembinaan berkelanjutan wirausaha mahasiswa; (2) pengembangan dan pemantaban kelembagaan program ke- wirausahaan mahasiswa di universitas; (3) pengembangan kurikulum pendidikan kewirausahaan; (4) pembentukan dan dinamisasi forum nasional kewirausahaan; dan promosi dan desiminasi program kewirausahaan kepada masyarakat luas.

\section{Manfaat}

Hasil penelitian pada aspek manfaat evaluasipun berkategori tinggi. Hal ini ditandai dengan tingginya respon masyarakat terhadap manfaat PMW. selain itu pula keberhasilan pengembangan PMW pada kedua universitas dapat ditinjau dari tiga aspek yakni kebermanfaatannya bagi mahasiswa, pengembangan dan peningkatan produktivitas usaha UKM sebagai bagian dari stakeholder, dan tercapainya tujuan universitas.

\section{Komponen Input}

\section{Pedoman Pelaksanaan}

Hasil penelitian pada aspek evaluasi pedoman pelaksanaan PMW berkategori tinggi. Hal ini dibuktikan dengan kedua universitas telah memiliki buku pedoman PMW yang diterbitkan oleh Dikti. Keberadaan buku pedoman pelaksanaan PMW sebagai rujukan utama dalam penyelenggaraan PMW diperoleh dari hasil sosialisasi PMW yang dilakukan oleh Dikti pada kegiatan-kegiatan kemahasiswaan, walaupun terkadang proses sosialisasi keberadaan buku pedoman mengalami keterlambatan dan terjadinya multi tafsir terhadap pedoman mengakibatkan penyelenggaraan PMW terhambat. Kendala demikian disebabkan karena adanya perubahan strukturisasi, dan regulasi anggaran DIPA pada setiap universitas.

Selain itu juga penyebaran buku pedoman dalam bentuk workshop, dan melalui pemanfaatan media sosial elektronik, sulit bagi universitas tertentu untuk mengimplementasikan dalam bentuk buku petunjuk teknis pelaksanaan program yang disesuaikan dengan kebutuhan setiap universitas dalam hal ini UB bermuara pada bidang sains dan teknologi dan UM bermuara pada bidang pendidikan dan pengajaran yang pada 
prinsipnya bertujuan untuk menjaga motivasi dan kreativitas mahasiswa.

\section{Struktur Organisasi}

Keberhasilan PMW pada kedua universitas tersebut merupakan cerminan kinerja terbaik dari pelaksana PMW yang memiliki integritas, dan komitmen yang tinggi sehingga hasil evaluasi pada aspek struktur organisasi berkategori tinggi. Hasil penelitian tersebut ditunjang dengan keberadaan panitia khusus pelaksana PMW pada kedua universitas yang berkerja di bawah koordinasi pembantu Rektor III pada setiap universitas. Panitia pelaksana PMW bekerja untuk merencanakan, melaksanakan, dan mengukur efektivitas pelaksanaan program. Berdasarkan aturan yang telah ditetapkan oleh Dikti, untuk menyiapkan/me-rencanakan PMW, tim bekerja selama 1-3 bulan efektif, yang terhitung mulai bulan JanuariMaret, kemudian proses pembekalan dan pelaksanaan program dilakukan selama 7 bulan terhitung dari bulan April-Oktober, sedangkan proses monitoring dan evaluasi program dilakukan pada bulan NovemberDesember.

\section{Mekanisme Pembiayaan}

Berdasarkan hasil penelitian pada aspek sumber dana berkategori tinggi pada kedua universitas sedangkan aspek alokasi dana berkategori moderat. Hal ini ditandai dengan sumber dana yang jelas baik bersumber pihak pemerintah, usaha mandiri universitas, maupun dari mitra kerjasama universitas. Namun hasil penelitian menunjukkan bahwa terdapat perubahan nomenklatur keuangan yang bersumber dari APBN dan PNBP menjadi tantangan tersendiri bagi penyelenggara PMW di kedua universitas.

Dengan adanya perubahan nomenklatur tersebut sangat berpengaruh pada besaran alokasi mata anggaran. Permasalahan yang mendasar lainnya adalah pemahaman konsep HIBAH yang keliru menganggap hibah merupakan pemberian bantuan dana cuma-cuma atau gratis dan tidak sedikit akan muncul embrio-embrio pengusaha berbasis proposal, maksudnya mahasiswa menjalan- kan usaha jika mendapat dana PMW, setelah tidak mendapat dana bantuan maka usaha yang dikembangkan mahasiswapun berakhir.

Dengan demikian, konsep hibah PMW kedepan merupakan pelimpahan dana PMW yang berasal dari APBN dan PNBP dari Dikti disalurkan dalam bentuk hibah ke rekening universitas, kemudian universitas memasukannya dalam Daftar Isian Penggunaan Anggaran (DIPA), kemudian dari universitas menyalurkan ke pengelola PMW kemudian pengelola PMW mengkompetisikan dana tersebut dalam bentuk dana bergulir ke peserta PMW.

Skema pembiayaan yang diterapkan pada kedua universitas tersebut berbeda satu dengan yang lain. UB secara konsisten pengalokasian pembiayaan PMW sejak tahun 2011-2014, alokasi pembiayaan sebesar 30\% untuk kebutuhan manajemen, dan $70 \%$ untuk kebutuhan alokasi bantuan dana mahasiswa. Formulasi pengalokasian pembiayaan PMW-UM, yang sama terjadi pada tahun 2011, pengalokasian sebesar 19,22\% untuk manajemen, dan 80,78\% untuk bantuan dana peserta PMW, akan tetapi sejak tahun 20122014, skema pengalokasian bantuan berbanding terbalik berdasarkan aturan dikti, dimana, alokasi untuk manajemen sebesar $71 \%$, dan untuk bantuan modal peserta PMW sebesar $29 \%$.

Tingginya alokasi anggaran untuk kebutuhan manajemen terjadi karena pelaksana PMW-UM merencanakan RAB untuk belanja honor output kegiatan, belanja barang non operasional lainnya, dan belanja perjalanan lainnya melampaui belanja bantuan modal mahasiswa, sedangkan realisasi dari setiap belanja tersebut hanya pada kisaran 30-40\%, sehingga sisa anggaran belanja yang tidak terserap tersebut dikembalikan ke bagian keuangan universitas. Faktor lain yang berpengaruh adalah karena menurunnya minat mahasiswa untuk berwirausaha dalam PMWUM setiap tahun.

\section{Kurikulum}

Penelitian menunjukkan bahwa hasil evaluasi pada aspek kurikulum dengan kategori rendah. Hal ini disebabkan kurikulum 
PMW belum terintegrasi dengan kurikulum akademik di universitas. Melalui pelaksanaan PMW idealnya dapat menunjang program kurikuler mahasiswa yang dibuktikan hampir seluruh perguruan tinggi telah mengembangkan mata kuliah kewirausahaan dengan kredit minimal dua Sistem Kredit Semester, dan Dikti telah mengembangkan modul kewirausahaan, buku panduan kewirausahaan, silabus, untuk meningkatkan PMW. Melalui mata kuliah Kewirausahaan dapat memberikan pengetahuan kewirausahaan, pengalihan pengalaman berwirausaha serta mendorong tumbuhnya motivasi berwirausaha, sebagai aktivitas awal mahasiswa yang berminat menjadi wirausahawan baru yang handal.

\section{Sarana dan Prasarana Penunjang}

Hasil evaluasi pada aspek sarana dan prasarana PMW dengan kategori tinggi. Hal ini ditandai dengan kesiapan universitas untuk menfasilitasi mahasiswa dengan mengoptimalkan sarana dan prasarana universitas yang ada. Untuk membekali mahasiswa dalam berwirausaha universitas telah memiliki unit kerja seperti PIBLAM UB, Unit bisnis UB dan lembaga pengembangan pendidikan dan pembelajaran (LP3) UM yang didesain dan dibangun untuk membekali mahasiswa dengan kompetensi tertentu untuk mewadahi minat usaha mahasiswa. Keberadaan lembaga tersebut sebagai upaya untuk mewujudkan pelayanan prima di universitas. Secara praktis, unit kerja tersebut banyak berurusan dengan upaya-upaya untuk menjaga kompetensi mahasiswa agar senantiasa dapat memenuhi tuntutan kebutuhan pasar usaha/pasar kerja. Muara dari pelayanan prima ini adalah kepuasan stakeholders utama universitas yang meliputi mahasiswa, dosen, karyawan, pengguna lulusan, serta pengguna hasil penelitian dan pengabdian masyarakat.

\section{Komponen Pelaksanaan}

Hasil evaluasi pada komponen proses terdiri dari delapan belas kriteria evaluasi yang diukur. Dari delapan belas aspek evaluasi tersebut terdapat dua belas aspek evaluasi dengan kategori tinggi, lima aspek evaluasi dengan kategori moderat, dan satu aspek yang berkategori rendah. Penjelasan lebih lanjut seperti berikut.

\section{Sosialisasi Program}

Hasil evaluasi pada aspek sosialisasi PMW menunjukkan hasil yang tinggi. Hal ini dikarenakan pelaksanaan sosialisasi keberadaan PMW pada kedua universitas tersebut telah berjalan sesuai dengan mekanisme dan kebutuhan setiap universitas, walaupun ditemukan pendekatan sosialisasi yang diterapkan oleh pelaksana PMW diluar dari ketentuan dikti. Oleh sebab itu, universitas diberi kesempatan untuk menyusun jadwal pelaksanaan sosialiasasi PMW kepada mahasiswanya sesuai dengan pedoman yang diterbitkan oleh Dikti, akan tetapi pihak universitas juga melakukan sosialisasi keberadaan PMW pada setiap penerimaan mahasiswa baru serta kegiatan kemahasiswaan lainnya. Penerapan sosialisasi keberadaan PMW pada saat penerimaan mahasiswa baru bertepatan pada bulan September merupakan hal yang tidak seharusnya dilakukan, alasannya karena dapat memperpendek masa pelaksanaan PMW, seharusnya bulan Maret atau April.

\section{Seleksi Peserta Program}

Pada aspek seleksi peserta PMW hasil evaluasi berkategori moderat. Hal ini terjadi karena kedua universitas menerapkan model seleksi yang berbeda. Misalkan saja UB menerapkan sistem kuota dan kompetisi. Sistem penentuan kuota penerima PMW dilakukan oleh UB berdasarkan kesepakatan pelaksana PMW-UB dengan pembantu Dekan setiap fakultas. Kuota standar yang diberikan oleh pelaksana adalah minimal masing-masing 4 (empat) unit usaha untuk setiap fakultas, namun tetap disesuaikan dengan kebutuhan program. Akan tetapi pola yang diterapkan oleh UM cukup berbeda, karena UM menerapkan sistem kompetisi sesuai dengan standar usaha yang telah ditetapkan.

Setiap mahasiswa menempuh proses seleksi yang ketat dengan tahapan telah lulus seleksi administrasi, memiliki perencanaan bisnis sesuai standar, dan lulus wawancara usaha. Berdasarkan hasil seleksi yang telah ditetapkan oleh pelaksana PMW, kebanyak- 
an mahasiswa kesulitan dalam pembuatan perencanaan usaha.

\section{Pelatihan dan Pembekalan}

Hasil evaluasi menunjukkan hasil dengan kategori tinggi. Karena kegiatan pendidikan dan pelatihan pada kedua universitas telah melibatkan para dosen, praktisi, pemerhati, dan lembaga mitra PMW lain yang memiliki integritas, komitmen, kompetensi dan pengalaman yang tinggi dalam kewirausahaan. Hal ini sebagaimana hasil penelitian Suwardie (2009, p. 159) menyatakan bahwa tamatan pelatihan memiliki cara pandang baru dalam melihat potensi peluang usaha. Selama kegiatan pelatihan dan pembekalan usaha, mahasiswa juga dilatih dan dibimbing oleh tim pendamping untuk menyusun proses pelaporan keuangan untuk mengetahui seberapa jauh pencapaian hasil dari keseluruhan usaha. Dengan begitu bisa diketahui berapa rata-rata pengeluaran dalam sebulan, dan berapa pendapatan bersih yang diperoleh setiap bulannya. Jadi proses evaluasi usaha secara menyeluruh dapat memberikan gambaran tentang perkembangan usaha dan bahan untuk merencanakan target pertumbuhan usaha mahasiswa selanjutnya.

\section{Magang dan Pendampingan Usaha}

Magang merupakan upaya untuk mempertemukan antara peserta PMW dengan Dosen Pembimbing dan Mitra Magang. Hasil evaluasi program pada aspek magang dan pendampingan usaha berkategori moderat. Hal ini disebabkan karena kegiatan magang kewirausahaan menjadi penting dan wajib diikuti oleh peserta, namun ada pengecualian bagi peserta yang telah mengikuti PKM dan program Co-op. Akan tetapi penafsiran kegiatan magang dari universitas cukup beragam, sehingga data temuan menunjukkan bahwa terdapat universitas menerapkan kegiatan magang usaha, dan terdapat pula universitas yang tidak menerapkan magang bahkan menggatikan dengan kegiatan lain sesuai dengan karakter perguruan tinggi yang lebih memilih hal-hal yang praktis. Untuk program magang ada pengecualian bagi mahasiswa yang pernah mengikuti program Co-op, $\mathrm{KKU}$, dan program kewirausahaan lain.

\section{Modal Usaha Awal}

Hasil evaluasi pada aspek modal usaha awal menunjukkan bahwa kedua universitas memiliki metode pencairan yang berbeda sehingga hasil evaluasi berkategori moderat. Hal ini disebabkan bahwa sejak dana PMW masuk dalam DIPA universitas pada awal tahun 2010, proses penyaluran modal usaha awal tidak tepat waktu. Hal ini disebabkan adanya perubahan DIPA anggaran pada kedua universitas. Revisi DIPA juga berdampak pada terlambatnya pelaksanaan program dan anggaran sehingga serapan anggaran universitaspun menjadi rendah. Strategi yang dilakukan oleh dikti adalah memajukan relokasi anggaran DIPA universitas anggaran pada setiap bulan Desember walaupun realisasinya pada bulan Maret, karena pada bulan Januari masih menyelesaikan laporan-laporan pada tahun sebelumnya, dan strategi demikian juga idealnya dilakukan universitas.

Semenjak diberlakukannya kebijakan anggaran PMW melalui DIPA universitas, berdampak pada pelaporan yang dilakukan oleh universitas tidak tepat waktu. Karena perguruan tinggi memiliki dinamika yang cukup tinggi. Dinamika dimaksudkan berkaitan dengan adanya perubahan strukturisasi dari pejabat lama ke yang baru, sehingga mekanisme kerja yang dipegang oleh pejabat lama sulit diadaptasi oleh pejabat yang baru, selain itu, komitmen dari pelaksana PMW pada setiap universitas yang masih rendah.

Selain itu, perubahan nomenklatur anggaran PMWpun berdampak pada kontrol dan pengawasan dari Dikti menjadi sangat terbatas. Idealnya dana yang dihibahkan harus di kompetisikan, bukan dijadikan grand hibah gratis, apalagi sudah dimasukan dalam DIPA Universitas karena akan sulit melakukan pengontrolan, evaluasi, dan penyampaian laporan. Berbeda dengan tahun 2009 dengan status dana kompetisi, pengawasan mau pun monitoring oleh dikti berjalan intensif sehingga dilihat pesertanya sungguhsungguh melaksanakan PMW, kalaupun ada yang belum berhasil mahasiswa akan diarahkan un- 
tuk terus belajar memperbaiki hal-hal yang kurang baik.

\section{Monitoring dan Evaluasi}

Hasil evaluasi pada aspek monitoring dan evaluasi pada kedua universitas tersebut berkategori tinggi. Hal ini ditandai dengan kedua universitas mengacu pada pedoman monitoring dan evaluasi yang telah ditetapkan oleh Dikti. Akan tetapi pada pelaksanaannya monitoring dan evaluasi memiliki kendala tersendiri bagi dikti, karena universitas memiliki respon yang berbeda-beda untuk menunjang setiap program laporan DIKTI. Kontrol yang dilakukan oleh dikti mengandalkan hasil audit dari Inspektorat Jendelal Dikti, rujukan inspektorat dalam melakukan monitoring pelaksanaan program adalah dari buku panduan PMW yang telah dikembangkan. Karena tugas monitoring yang dilakukan oleh inspektorat adalah berkaitan dengan laporan keuangan bukan pada laporan pelaksanaan program. Jika dalam pelaksanaan PMW keluar dari arahan dan petunjuk buku pedoman, maka menjadi temuan yang kemudian berdampak pada pengalokasian anggaran tahun berikutnya. Kalaupun sanksi yang diberikan dari pengurangan alokasi DIPA, universitas tetap mencari sumber pendanaan lain melalui kerjasama dengan mitra lembaga keuangan lainnya.

\section{Komponen Keluaran}

Evaluasi pada komponen output terbagi dalam dua aspek evaluasi yakni: jumlah mahasiswa peserta PMW dengan kategori berhasil dalam berwirausaha; dan jumlah unit usaha baru mahasiswa. Adapun hasilnya sebagai berikut.

\section{Jumlah Mabasiswa yang Wirausaba}

Hasil evaluasi pada aspek jumlah mahasiswa yang menjadi wirausaha dengan capaian evaluasi berkategori rendah. Hal ini disebabkan dalam kurung waktu 2011-2014, terdapat 820 mahasiswa yang berusaha. Hal ini menunjukkan bahwa motivasi mahasiswa untuk berwirausaha cukup tinggi. Akan tetapi dari hasil penelitian PMW dengan banyaknya jumlah wirausaha tersebut bukan berarti setiap tahun mengalami peningkatan, malahan cenderung menurun sebesar 35,5\%. Hal ini disebabkan karena pola pikir mahasiswa dengan berwirausaha sambil kuliah akan menghambat proses akademik sehingga minat mahasiswa berkurang.

Sebagaimana hasil penelitian Suyanto \& Ariadi (2015, p. 120) menunjukkan bahwa hanya $32 \%$ lulusan perguruan tinggi yang berhasil membangun usaha mandiri dengan rentang waktu rintisan membangun usaha antara 3-6 tahun. Kesulitan yang dihadapi dalam membangun usaha diantaranya modal yang terbatas, pemilihan jenis usaha dan terbatas koneksitas usaha.

Dari aspek PMW perubahan nomenklatur anggaran PMW juga memberikan kontribusi terhadap menurunnya jumlah mahasiswa yang terlibat dalam wirausaha, karena alokasi anggaran yang terbatas, disamping itu rendahnya daya serap anggaran untuk bantuan mahasiswa akibat dari kesalahan perencanaan anggaran seperti yang terjadi pada pelaksanaan PMW-UM pada tahun 2013 dan 2014 sehingga dana dikembalikan ke bagian keuangan universitas.

\section{Unit Usaha Mahasiswa}

Hasil evaluasi pada aspek jumlah unit usaha mahasiswa dengan kategori rendah. $\mathrm{Hal}$ ini disebabkan terjadinya penurunan minat dan motivasi mahasiswa untuk bergabung dan menyelenggarakan PMW. Hasil penelitian ini pula sesuai dengan penelitian yang dilakukan oleh Budiyanto, Suprapto, \& Poerwoningsih (2017, p. 393) menyimpulkan bahwa terdapat $40 \%$ mahasiswa yang berhasil menjadi wirausaha baru dengan keunggulan ipteks pada bidang produk kerajinan, makanan, dan jasa persewaan.

Dari perpektif jenis usaha, rata-rata mahasiswa mengembangkan usaha tidak sesuai dengan disiplin ilmu yang dimiliki, karena pengembangan usaha berdasarkan potensi dan kondisi pasar, misalnya karena Kota Malang Raya merupakan kota pariwisata, mahasiswa cenderung memilih usaha di bidang boga/makanan dan minuman.

Pada umumnya kondisi ini terjadi pada mahasiswa yang tidak mempunyai kemam- 
puan teknis yang cukup misalkan mahasiswa program studi tehnik yang bergerak dibidang budidaya ikan, budidaya lele, atau membuat restoran warung makan dan lain-lain sebenarnya bukan itu prioritas dalam PMW, akan tetapi yang diinginkan dari mahasiswa teknik itu dari sisi keilmuan mengembangkan usaha PMW sesuai dan relevan dengan kompetensi dan disiplin ilmu yang dimiliki.

\section{Simpulan}

Berdasarkan hasil evaluasi dari tiga puluh kriteria keberhasilan program sebagaimana pada Tabel 2 penelitian ini, ditemukan bahwa terdapat dua puluh kriteria evaluasi yang berkategori tinggi, enam kriteria evaluasi yang berkategori moderat, dan empat kriteria evaluasi yang berkategori rendah. Ini berarti bahwa secara umum pelaksanaan PMW pada kedua universitas yang menjadi fokus penelitian ini telah berjalan berdasarkan kriteria standar objektif yang ditetapkan.

Berdasarkan hasil penelitian yang diuraikan pada pokok kesimpulan tersebut, rekomendasi yang dapat diberikan pada penelitian ini yaitu sebagai berikut.

Pertama, rekomendasi yang dapat diberikan kepada Direktorat Pembelajaran dan Kemahasiswaan Pendidikan Tinggi sebagai pengelola PMW Nasional diharapkan untuk: (1) mengevaluasi pelaksanaan PMW secara nasional, (2) mengupayakan agar nomenklatur dana PMW dikembalikan menjadi dana bergulir yang dikompetisikan ke setiap universitas, (3) meningkatkan alokasi dana PMW setiap tahun, (4) proses monitoring dan evaluasi pada PMW diharapkan untuk diberlakukan sama seperti tridarma lainnya yang dilakukan secara intensif dan sistematis; (5) mendorong gerakan kewirausahaan nasional melalui pemberdayaan universitas dengan program-program kewirausahaan; dan (6) memberikan sanksi dan penghargaan bagi universitas yang melanggar dan berhasil dalam pelaksanaan PMW.

Kedua, rekomendasi yang dapat diberikan kepada pelaksana dan civitas akademika di universitas yaitu supaya dapat: (1) mengevaluasi pelaksanaan PMW di tingkat universitas; (2) mempercepat proses pencairan DI-
PA universitas; (3) melaksanakan dan menyalurkan dana bantuan PMW tepat waktu sesuai dengan stadar dan mekanisme yang telah ditetapkan secara nasional; (4) merencanakan dan mengalokasikan anggaran PMW kepada mahasiswa sesuai ketetapan, (5) verkoordinasi dengan Direktorat Pembelajaran dan Kemahasiswaan Pendidikan Dikti verkaitan dengan perubahan nomenklatur dana PMW yang semula DIPA universitas menjadi Hibah bergulir yang dikompetisikan ke mahasiswa; (6) membentuk tim pelaksanaan PMW yang permanen yang terintegrasi dengan struktur universitas; (7) membentuk unit-unit kewirausahaan mahasiswa pada setiap fakultas; (8) meningkatkan kerjasama dengan lembaga mitra universitas dengan memperdayakan dana bantuan sosial/dana CSR untuk kegiatan kewirausahaan mahasiswa; dan (9) menetapkan dan menerapkan mata kuliah kewirausahaan sebagai mata kuliah wajib di universitas.

Ketiga, rekomendasi yang dapat diberikan kepada mahasiswa adalah supaya: (1) meningkatkan minat dan partisipasinya dalam kegiatan kewirausahaan di universitas; (2) mengembangkan PMW secara berkelompok dan terintegrasi dari berbagai disiplin ilmu; (3) mengembangkan usaha yang berbasis teknoentrepreneur sesuai dengan disiplin ilmu; (4) memberikan pelaporan perkembangan secara berkala kepada pelaksana PMW di tingkat universitas; dan (5) meningkatkan kapasitas dan kapabilitas individu dan kelompok dalam PMW.

Keempat, rekomendasi yang dapat diberikan kepada lembaga mitra PMW yaitu agar dapat: (1) meningkatkan kerjasama dengan universitas melalui pemberian dana bantuan sosial/CSR lembaga mitra; (2) memperdayakan mahasiswa sukses berusaha sebagai mitra lembaga; (3) memberikan bantuan dana kredit ke mahasiswa yang sukses dalam berusaha; (4) meningkatkan peran dalam pembinaan dan pendampingan usaha mahasiswa; dan (5) bekerja sama dengan mahasiswa untuk meningkatkan profit usaha mahasiswa. 


\section{Daftar Pustaka}

Akbar, S. (2007). Pembelajaran nilai kewirausahaan dalam perspektif pendidikan umum: prinsip-prinsip dan vektor-vektor percepatan proses internalisasi nilai kewirausahaan. Malang: UM Press.

Alma, B. (2011). Kewirausahaan untuk mahasiswa dan umum. Bandung: Alfabeta.

Ariyanti, F. (2013). RI mimpi punya wirausaha sebesar Amerika Serikat. Retrieved December 8, 2013, from https://www.liputan6.com/bisnis/rea d/631916/ri-mimpi-punya-wirausahasebesar-amerika-serikat

Badan Pusat Statistik. (2013). Perkembangan beberapa indikator utama sosial-ekonomi Indonesia Agustus 2013. Jakarta: Badan Pusat Statistik.

Badan Pusat Statistik Provinsi Jawa Timur. (2014). Tingkat pengangguran terbuka (TPT) di Jawa Timur pada Agustus 2014. Jawa Timur: Badan Pusat Statistik Provinsi Jawa Timur.

Budiyanto, H., Suprapto, A., \& Poerwoningsih, D. (2017). Program pengembangan kewirausahaan dalam bentuk inkubator bisnis di perguruan tinggi bagi mahasiswa pemilik usaha pemula. In Seminar Nasional Sistem Informasi (pp. 385-394). Malang: Fakultas Teknologi Informasi Universitas Merdeka Malang. Retrieved from https://www.researchgate.net/publica tion/319999057.

Bygrave, W. D. (2010). The entrepreneurial proces. In W. D. Bygrave \& A. Zacharakis (Eds.), The Portable MBA in Entrepreneurship. New Jersey: John Wiley \& Sons, Inc.

Cantillon, R. (2010). Essay sur la nature du commerce un general (An essay on economic theory). (C. Saucier, Trans.). Auburn: Mises Intitute.

Ciputra. (2008). Ciputra quantum leap:
Entrepreneurship mengubah masa depan bangsa dan masa depan anda. Jakarta: PT. Elex Media Komputindo.

Direktorat Jenderal Pendidikan Tinggi Kementerian Pendidikan dan Kebudayaan. (2009). Rencana Strategis 2010-2014. Jakarta: Direktorat Jenderal Pendidikan Tinggi Kementerian Pendidikan dan Kebudayaan.

Hisrich, R. D., Peters, M. P., \& Shepherd, D. A. (2008). Kewirausabaan. (C. Sungkono \& D. Angelica, Trans.). Jakarta: Salemba Empat.

Lawshe, C. H. (1975). A quantitative approach to content validity. Personnel Psychology, 28(4), 563-575. https://doi.org/10.1111/j.17446570.1975.tb01393.x

Pusat Data Statistik Pendidikan. (2014). Proyeksi data tingkat perguruan tinggi tabun 2013/2014-2020/2021. Jakarta: Pusat Data Statistik Pendidikan.

Scheerens, J., Glas, C., \& Thomas, S. M. (2003). Educational Evaluation, Assessment, and Monitoring: A Systemic Aproach. Lisse: Swets \& Zeitlinger B. $\mathrm{V}$.

Siradjuddin, E. (2009). Memerangi sindrom negara gagal transformasi Indonesia 2020 mencapai negara entrepreneur maju. Jakarta: Kata Hasta Pustaka.

Soenarto, S., Amin, M. M., \& Kumaidi, K. (2017). Evaluasi implementasi kebijakan Sekolah Menengah Kejuruan program 4 tahun dalam meningkatkan employability lulusan. Jurnal Penelitian Dan Evaluasi Pendidikan, 21(2), 215. https://doi.org/10.21831/pep.v21i2.1 7076

Subianto, P. (2013). Membangun kembali Indonesia Raya: strategi besar transformasi bangsa. Jakarta: Institut Garuda Nusantara.

Sutopo, A. (2012). Evaluasi efektivitas unit produksi dalam mempersiapkan kompetensi kerja siswa SMK. Jurnal 
Penelitian Dan Evaluasi Pendidikan, 16(2). Retrieved from

https://journal.uny.ac.id/index.php/jp ep/article/view/1124

Suwardie, S. (2009). Model evaluasi kinerja tamatan pelatihan kewirausahaan Balai Diklat Pertanian DIY. Jurnal Penelitian Dan Evaluasi Pendidikan, 13(2).

Retrieved from

https://journal.uny.ac.id/index.php/jp ep/article/view/1407

Suyanto, B., \& Ariadi, S. (2015). Upaya pengembangan usaha mandiri di kalangan pengangguran terdidik di Jawa Timur. Jurnal Masyarakat, Kebudayaan, Dan Politik, 28(3), 115124.

Tilaar, H. A. R., \& Nugroho, R. (2012). Kebijakan pendidikan. Yogyakarta: Pustaka Pelajar. 